\title{
PENGEMBANGAN WISATA LOKAL DI PESISIR MANGGAR KOTA BALIKPAPAN UNTUK PENINGKATAN PEREKONOMIAN MASYARAKAT SEKITAR
}

\author{
Didik Hadiyatno ${ }^{1}$, Nina Indriastuty ${ }^{2}$, Ulum $\mathrm{Janah}^{3}$ \\ ${ }^{1,2,3}$ Universitas Balikpapan \\ Email: didik.hadiyatno@uniba-bpn.ac.id
}

\begin{abstract}
The eastern region of Balikpapan is dominated by fishing communities in Manggar. In this region, there are attractions Manggar Beach. The government and the surrounding community have used both elements in their daily activities. However, the utilization is still not maximal. Although the government has improved the coastal infrastructure, it is still necessary to develop human resources in order for the economy through tourism to materialize. Through strategic stages, namely (1) data collection; (2) analyzing data; (3) presentation of the result of data analysis, expected to get data to become picture and consideration of government and society around in improving economy area especially tourism with community profession partly as a fisherman. The findings in the tourism sector have yet to show results for the economy in Manggar. This is because the creativity and innovation of human resources have not been optimized by the community and local government. The potential of the community actually exists to be developed in the tourism sector. This can be done through training the management of fishery products by following the global development so as to attract domestic and foreign tourists, making the coastal area as a tourist destination of choice.
\end{abstract}

Keywords: Development Of Tourism, Economy, Society

\begin{abstract}
Abstrak. Wilayah timur Balikpapan didominasi oleh masyarakat nelayan di Manggar. Di wilayah ini terdapat objek wisata Pantai Manggar. Pemerintah maupun masyarakat sekitar telah memanfaatkan kedua unsur tersebut dalam aktivitas keseharian. Namun, pemanfaatan tersebut masih belum maksimal. Walaupun pemerintah telah memperbaiki infrastruktur di pantai tersebut, masih perlu pengembangan SDM agar perekonomian melalui pariwisata dapat terwujud. Melalui tahapan strategis, yaitu (1) pengumpulan data; (2) penganalisisan data; (3) penyajian hasil analisis data, diharapkan diperoleh datadata untuk menjadi gambaran dan pertimbangan pemerintah serta masyarakat sekitar dalam meningkatkan perekonomian daerah khususnya pariwisata dengan profesi masyarakat sebagian sebagai nelayan. Hasil temuan di sektor pariwisata belum menampakkan hasil bagi perekonomian di Manggar. Hal tersebut dikarenakan kreatifitas dan inovasi SDM belum dioptimalkan oleh masyarakat dan pemerintah setempat. Potensi yang dimiliki masyarakat sebenarnya telah ada untuk dikembangkan di sektor pariwisata. Hal tersebut dapat dilakukan melalui pelatihan pengelolaan hasil perikanan dengan mengikuti perkembangan global sehingga menarik wisatawan dalam negeri maupun mancanegara, menjadikan wilayah pesisir sebagai tempat wisata pilihan.
\end{abstract}

Kata Kunci: Pengembangan Wisata, Perekonomian, Masyarakat

\section{PENDAHULUAN}

Pariwisata merupakan salah satu modal dalam peningkatan pendapatan suatu daerah. Beberapa bidang dalam pariwisata yang ada dari segi budaya maupun alam sering kali ditonjolkan. Salah satu segi budaya yang dapat memberikan peningkatan pendapatan daerah adalah melalui sistem mata pencaharian masyarakat sekaligus berhubungan dengan potensi alamnya.

Nelayan merupakan bagian dari mata pencaharian masyarakat, khususnya di wilayah timur Kota Balikpapan, di daerah pesisirnya akan membawa dampak yang lebih baik bagi peningkatan ekonomi daerah jika dikelola secara baik. Hasil tangkapan ikan oleh nelayan yang melimpah dapat berimbas pada peningkatan pariwisata karena hasilnya dapat dijadikan berbagai produk kuliner sebagai buah tangan bagi wisatawan yang berkunjung jika masyarakat dan pemerintah dapat berinovasi dalam mengelola tangkapannya.

Selain itu, pemberdayaan masyarakat menurut Sumodiningrat merupakan upaya untuk memandirikan masyarakat lewat perwujudan potensi kemampuan yang dimiliki oleh masyarakat tersebut. Potensi masyarakat 
berkenaan dengan mata pencaharian dan alam sebagai pendukungnya secara kreatif dan inovatif serta promosi dan pemasaran yang strategis dapat memberikan peningkatan pada perekonomian masyarakat sekitar (Harto, 2014).

Wilayah timur Kota Balikpapan didominasi oleh masyarakat nelayan khususnya di daerah pesisir Manggar. Di wilayah ini juga terdapat objek wisata yaitu Pantai Manggar. Baik pemerintah maupun masyarakat sekitar telah memanfaatkan kedua unsur tersebut dalam aktivitas sehari-hari masyarakat di daerahh Manggar. Namun, pemanfaatan tersebut masih belum maksimal. Walaupun pemerintah telah memperbaiki infrastruktur yang terdapat di pantai tersebut, masih perlu adanya pengembangan SDM di masyarakat sekitar agar tingkat perekonomian melalui pariwisata di Pantai Manggar dapat terwujud.

Sementara itu, masyarakat sekitar juga telah memanfaatkan kondisi tersebut dengan membuka usaha di sepanjang pesisir Manggar baik di wilayah Pantai Manggar maupun di luarnya. Seperti pernyataan dari Djula, peneliti sebelumnya yang mengungkapkan berkembangnya berbagai usaha kecil dan menengah di tengah-tengah masyarakat saat ini merupakan fenomena yang patut disyukuri. Hal ini sebagai isyarat bahwa keberadaan usaha kecil dan menengah telah mendapat tempat yang penting dalam proses pertumbuhan ekonomi dan memberdayakan sumber daya alam yang ada. Terutama para nelayan yang mendirikan usaha kecil sebagai modal untuk melangsungkan taraf hidup mereka. Hadirnya berbagai macam usaha memberikan kesempatn yang seluas-luasnya kepada masyarakat serta menyadarkan akan pentingnya melakukan perubahan dalam meningkatkan taraf hidup masyarakat dari usaha mereka yang sekaligus dapat meningkatkan perekonomian daerah (Djula, 2013).

Berdasarkan hal tersebut pengabdian mengenai Pengembangan Wisata Lokal di Pesisir Manggar Kota Balikpapan untuk Peningkatan Perekonomian Masyarakat Sekitar sangat penting dilakukan. Dengan memberikan bekal pelatihan SDM masyarakat sekitar untuk berinovasi melalui produk-produk yang mereka miliki dari hasil nelayan dan promosi serta pemasaran yang menunjang akan dapat memberikan dampak perekonomian yang lebih baik bagi mereka serta tingkat pariwisata yang meningkat juga akan dapat berimbas pula pada pendapatan daerah.

\section{Sumber Daya alam}

Sumber alam (natural resources/endoment factors) pada prinsipnya dapat dikategorikan menjadi 3 bagian, yaitu:

a. Sumber daya alam yang tidak pernah habis (Renewable-perpetual resources). Sumber ini seperti sinar matarhari, angina, gelombang laut, dan sebagainya.

b. Sumber daya alam yang tidak dapat diperbarui (Non-renewable or exhaustible resources). Sumber ini seperti minyak, gas alam, uranium, batubara serta mineral yang nonenergi contohnya tembaga, nikel, aluminum dan lain-lain.

c. Sumber alam yang potensial untuk diperbarui (Pottentially Renewable Resources) seperti pohon-pohon di hutan, rumput dipandang rumput deposit air tanah, dan sebagainya.

\section{Sumber Daya Manusia}

Sumber daya manusia merupakan poros pembangunan ekonomi baik dalam skala global, nasional maupun daerah. Strategi pembangunan dengan basis ini dianggap sangat relevan dan cocok dengan kondisi dan karakter pembangunan ekonomi di negara-negara berkembang sejak era 80-an.

Dengan kualitas sumber daya manusia yang semakin meningkat, akan dapat mendorong peningkatan produktifitas ekonomi sekaligus sebagai modal dasar untuk memacu pertumbuhan ekonomi (Junaidi \& Zulgani, 2011).

Pembangunan kepariwisataan merupakan bagian dari pembangunan nasional mempunyai tujuan antara lain memperluas kesempatan berusaha dan lapangan kerja. Kompleksitas dalam pembangunan tidak terlepas dari kemauan para pemangku kebijakan untuk menggerakkan sektor pariwisata sebagai salah satu pendapatan daerah yang dapat diandalkan.

Di setiap provinsi memiliki keunggulan daerah yang dapat diandalkan sebagai pendapatan daerah. Dengan adanya kekayaan alam diperlukan tenaga kerja yang memiliki keahlian dan kemampuan yang sesuai dengan bidangnya 
sehingga penelolaan tersebut menjadi terarah dan tidak keluar jalur.

Banyak kendala yang dihadapi dalam pembangunan wisata didaerah, namun dari semua itu sumber daya manusia sebagai pengolah merupakan faktor kunci dalam pembangunan pariwisata daerah. Kemampuan dari sumber daya manusia yang mengelola pariwisata daerah haruslah memiliki kemampuan yang baik dalam keilmuan sehingga dapat menerapkannya pada saat bekerja nanti (Anugrah \& Sudarmayasa, 2017).

\section{Pengelolaan Co-Management Sumberdaya Perikanan dan Pariwisata pada Pengembangan Ekonomi Masyarakat Pesisir}

Arifin menyatakan co-management memadukan antara unsur masyarakat pengguna (kelompok nelayan, pengusaha perikanan, dll.) dan pemerintah yang menghindari peran dominan yang berlebihan dari satu pihak dalam pengelolaan sumberdaya pesisir dan laut sehingga pembiasaa aspirasi pada satu pihak dapat dieliminasi. Dalam jangka panjang, pelaksanaan co-management ini diyakini akan memberikan perubahan-perubahan ke arah yang lebih baik yaitu: 1) meningkatkan kesadaran masyarakat akan pentingnya sumberdaya pesisir dan laut dalam menunjang kehidupan, 2) meningkatkan kemampuan masyarakat, sehingga mampu berperan serta dalam setiap tahapan pengelolaan secara terpadu, 3) meningkatkan pendapatan masyarakat dengan bentuk-bentuk pemanfaat yang lestari dan berkelanjutan serta berwawasan lingkungan (Witarsa, 2015).

Dengan model co-management tersebut, masyarakat pesisir dalam hal ini nelayan dapat memanfaatkan profesi sekaligus hasil tangkapannya dalam memajukan sektor pariwisata dengan bantuan pelatihan pengelolaan baik sumber daya alam dan sumber daya manusia dari pemerintah. Di sisi lain, pemerintah pun dapat terbantu dari masyarakat dalam peningkatan perekonomian daerah jika masyarakat pesisir dapat mengembangkan potensi mereka dalam mengelola hasil tangkapan dan kreatifitas serta inovasi mereka ke beberapa produk kuliner, produk wisata pantai dengan memanfaatkan profesi nelayan untuk mengenalkan pengetahuan akan budidaya beberapa spesies habitat laut yang memancing minat wisatawan. Dengan demikian, perekonomian masyarakat pesisir khususnya nelayan juga dapat meningkat.

\section{METODE PELAKSANAAN}

Penelitian ini dilakukan melalui tiga tahapan strategis, yaitu (1) pengumpulan data; (2) penganalisisan data; (3) penyajian hasil analisis data (pelaporan). Pengumpulan data dilakukan melalui metode survey dengan teknik wawancara dan teknik kuesioner, serta kajian dokumen. Tenaga lapangan langsung turun ke lokasi penelitian untuk melakukan wawancara mendalam (indeep interview) dan pengisian kuesioner.

Analisis data merupakan proses penataan data secara sistematis berdasarkan hasil wawancara dan kuesioner untuk ditelaah berdasarkan tujuan penelitian sehingga diketahui kecenderungan makna yang terkandung. Data hasil wawancara dan kuesioner dilakukan perampatan secara induktif-abstrak yang melintas dari tingkat konkrit ke tingkat abstrak melalui konseptualisasi.

Konseptualisasi data ini dilakukan melalui tiga siklis, yaitu (1) reduksi data, (2) organisasi data, dan (3) interpretasi data. Tahap reduksi data meliputi tahap manipulasi, pengintegrasian, mentransformasikan dan pencatatan data ketika dipresentasikan. Reduksi data dimaksudkan untuk membantu dalam pengklasifikasian aspekaspek penting dari isu yang dikaji. Tahap organisasi data merupakan tahap pengumpulan data yang terkait pada tema-tema, butir-butir pemikiran tertentu, dan membuat kategorikategori yang lebih spesifik. Adapun interpretasi data adalah tahap membuat rampatan-rampatan yang berkaitan dengan tujuan penelitian (Harto, 2014).

Penelitian ini di kota Balikpapan daerah pesisir Manggar. Penentuan lokasi penelitian ini dengan pertimbangan bahwa dilihat dari mata pencarian penduduk lebih banyak di laut dan profesinya sebagian besar penduduknya adalah sebagai nelayan serta dilihat dari sumber daya alam terdapat wisata pantai yang bisa dikembangkan sehingga dapat menjadi salah tujuan pariwisata. 


\section{HASIL DAN PEMBAHASAN}

\section{Letak Geografis Daerah Manggar}

Kota Balikpapan memiliki wilayah $85 \%$ berbukit-bukit serta $12 \%$ berupa daratan datar yang sempit yang terutama berada di daerah aliran sungai dan sungai kecil serta pesisir pantai. Dengan kondisi tanah yang bersifat asam (gambut) serta dominan tanah merah yang kurang subur, sebagaimana layaknya wilayah lain di Indonesia, kota Balikpapan juga beriklim tropis.

Kota ini berada di pesisir timur Kalimantan yang langsung berbatasan dengan Selat Makassar, memiliki teluk yang dapat dimanfaatkan sebagai pelabuhan laut komersial dan pelabuhan minyak. Sehubungan dengan pemekaran wilayah kecamatan, maka melalui keputusan gubernur kepala daerah tingkat I Kalimantan Timur No. 19 th. 1996, maka sejak tanggal 15 Oktober 1996 ditetapkan 7 (tujuh) kelurahan persiapan menjadi kelurahan definitif dan pada tanggal 17 Mei 1996, ditetapkan pula mengenai keputusan gubernur kepala daerah tingkat I Kalimantan Timur, perubahan status desa Manggar Baru menjadi kelurahan Manggar Baru secara definitif.

Berdasarkan data yang diperoleh, secara geografis, kelurahan Manggar terletak di wilayah timur kota Balikpapan dengan luas 3.525,50 ha dan terletak antara 1 LS-1,5 LS dan 116,5 BT117,5 BT.

Keadaan topografi kelurahan Manggar berada pada daratan rendah atau pantai dengan ketinggian $0,25 \mathrm{~m}$ dari permukaan air laut.
Banyaknya curah hujan kelurahan Manggar adalah $2.948 \mathrm{~mm} /$ tahun dengan suhu udara 27,80 C.

\section{Perekonomian Masyarakat Manggar}

Kota Balikpapan merupakan pintu gerbang wilayah Indonesia Timur. Hal ini sesuai dengan kedudukannya sebagai kota jasa atau kota transit yang dilengkapi dengan fasilitas jasa dan transportasi. Balikpapan sebagai gerbang wilayah atau regional, ditandai dengan keberadaan bandara internasional atau pelabuhan laut utama serta pelabuhan pengumpan regional yang lengkap dibanding kawasan lain di Kalimantan bahkan di wilayah Indonesia Timur.

Balikpapan merupakan simpul utama kegiatan di Kalimantan Timur, mengingat kota ini merupakan jalur distribusi dan outlet dari dan ke kabupaten atau kota dan provinsi Kalimantan Timur. Oleh karena itu, kota Balikpapan memiliki komoditi unggulan yang dihasilkan oleh masing-masing wilayah, baik sektor pertanian maupun dari sektor industri pengolahan yang memanfaatkan bahan baku hasil pertanian.

Berdasarkan sumber data yang diperoleh, perekonomian masyarakat Manggar pada tahun 2012/2013 sebagai berikut

Tabel 1. Perekonomian Masyarakat Manggar pada Tahun 2012/2013

\begin{tabular}{|c|c|c|c|c|}
\hline \multirow[b]{2}{*}{ NO } & \multirow[b]{2}{*}{ INDIKATOR } & \multirow[b]{2}{*}{ SUB INDIKATOR } & \multicolumn{2}{|c|}{ TAHUN } \\
\hline & & & 2012 & 2013 \\
\hline \multirow{4}{*}{1.} & \multirow[t]{4}{*}{ Pengangguran } & $\begin{array}{l}\text { 1. Jumlah penduduk usia kerja } 15-56 \\
\text { th }\end{array}$ & $22-419$ orang & 23.191 orang \\
\hline & & $\begin{array}{l}\text { 2. Jumlah penduduk usia } 15-56 \text { th } \\
\text { tidak kerja }\end{array}$ & 4.481 orang & 4.481 orang \\
\hline & & 3. Penduduk wanita usia $15-56$ th IRT & 4299 orang & 4299 orang \\
\hline & & $\begin{array}{l}\text { 4. Penduduk usia }>15 \text { th cacat } \\
\text { sehingga tidak bisa bekerja }\end{array}$ & 0 & 0 \\
\hline \multirow{6}{*}{2.} & \multirow[t]{6}{*}{ Pendapatan } & Sumber Pendapatan & & \\
\hline & & 1. Pertanian & Rp. 1.980 .000 .000 & Rp. 2.376 .000 .000 \\
\hline & & 2. Kehutanan & 0 & 0 \\
\hline & & 3. Perkebunan & Rp. 578.900.000 & Rp. 705.600 .000 \\
\hline & & 4. Peternakan & Rp. 697.000.000 & Rp. 751.000 .000 \\
\hline & & 5. Perikanan & Rp. 864.000.000 & Rp. 1.008 .000 .000 \\
\hline
\end{tabular}




\begin{tabular}{lcc} 
6. Perdagangan & Rp. 5.861 .300 .000 & Rp. 6.835 .800 .000 \\
\hline 7. Jasa & Rp. 4.725 .000 .000 & Rp. 5.281 .500 .000 \\
\hline 8. Usaha penginapan dan sejenisnya & Rp. 86.200 .000 & Rp. 86.200 .000 \\
\hline 9. Pariwisata & 0 & 0 \\
\hline 10. Industri rumah tangga & Rp. 416.600 .000 & Rp. 416.600 .000 \\
\hline
\end{tabular}

kelompok masyarakat lain. Kondisi masyarakat

Dari data di atas dapat dilihat sektor pariwisata belum menampakkan hasil bagi perekonomian di Masyarakat Manggar. Hal tersebut dapat dikarenakan kreatifitas dan inovasi yang dimiliki SDM di sana belum dioptimalkan oleh masyarakat itu sendiri dan juga pemerintah setempat.

Kondisi tersebut khususnya di wilayah pesisir, masyarakat nelayan atau masyarakat pesisir merupakan kelompok yang retalif tertinggal secara ekonomi, sosial (khusunya dalam hal akses pendidikan dan layanan kesehatan, dan kultural dibandingkan dengan pesisir atau masyarakat nelayan di berbagai kawasan pada umumnya ditandai oleh adanya beberapa ciri, seperti kemiskinan, keterbelakangan sosial-budaya, rendahnya sumberdaya manusia (Fatmasari, 2014).

\section{Mata Pencaharian Masyarakat Manggar}

Sistem mata pencaharian di kawasan Manggar sampai Teritip cukup berbeda satu sama lain meskipun sama-sama berada di area pesisir Balikpapan. Beberapa warga daerah memiliki spesifikasi-spesifikasi tertentu yang membantu untuk bisa membedakan pekerjaan warga di kawasan-kawasan ini.

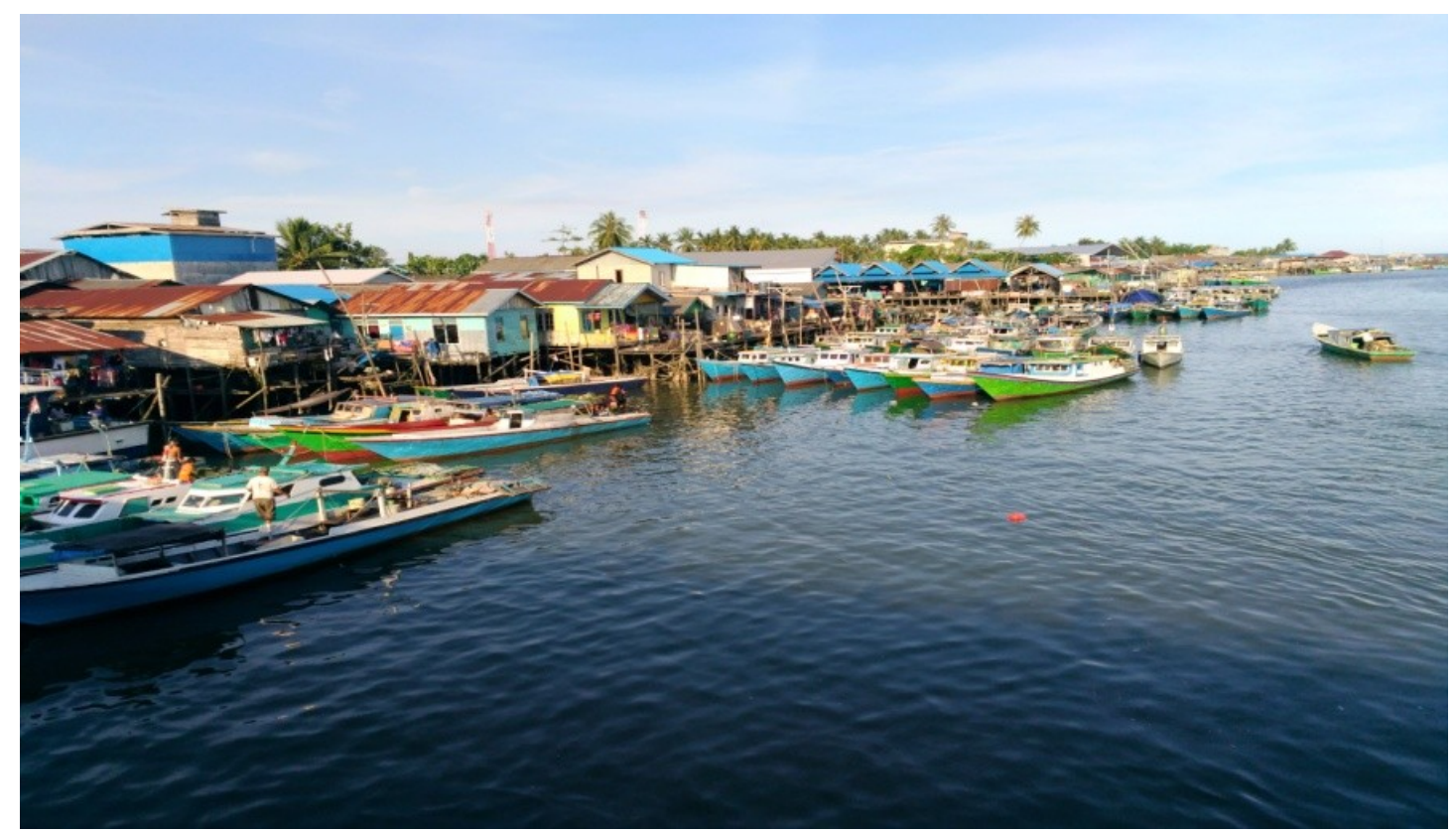

Gambar 1 Kapal-kapal Pemancing Ikan di Perkampungan Nelayan Manggar

Mata pencaharian mayoritas masyarakat Manggar adalah nelayan dan pedagang. Nelayannelayan di perkampungan nelayan Manggar umumnya hanya menggunakan kapal-kapal kecil untuk memancing ikan, dan kapal yang lebih besar biasanya milik juragan sekitar yang menyediakan modal dan sarana untuk memancing. Proses pemancingannya pun masih tradisional dengan menggunakan jala-jala secara manual dan dilakukan dengan kapal yang berkelompok.

Di Perkampungan Nelayan ini juga sudah disediakan Pangkalan Pendaratan Ikan (PPI) atau umumnya juga disebut Tempat Pengumpulan Ikan. Di PPI ini ada orang yang bekerja sebagai distributor, atau tengkulak dalam sebutan lokal. Banyak nelayan tradisional di kampung ini membuat rumpon, jaring dan alat sendiri yang biasanya dilakukan saat mereka tidak melaut. 
Untuk menanggulangi saat-saat dimana keadaan laut tidak memungkinkan bagi para nelayan untuk melaut, masyarakat sekitar biasanya beralih ke petani-petani tambak di untuk memanen ikan-ikan yang dibudidayakannya. Ikan yang umum untuk ditambakkan di daerah Manggar ini adalah ikan bandeng.

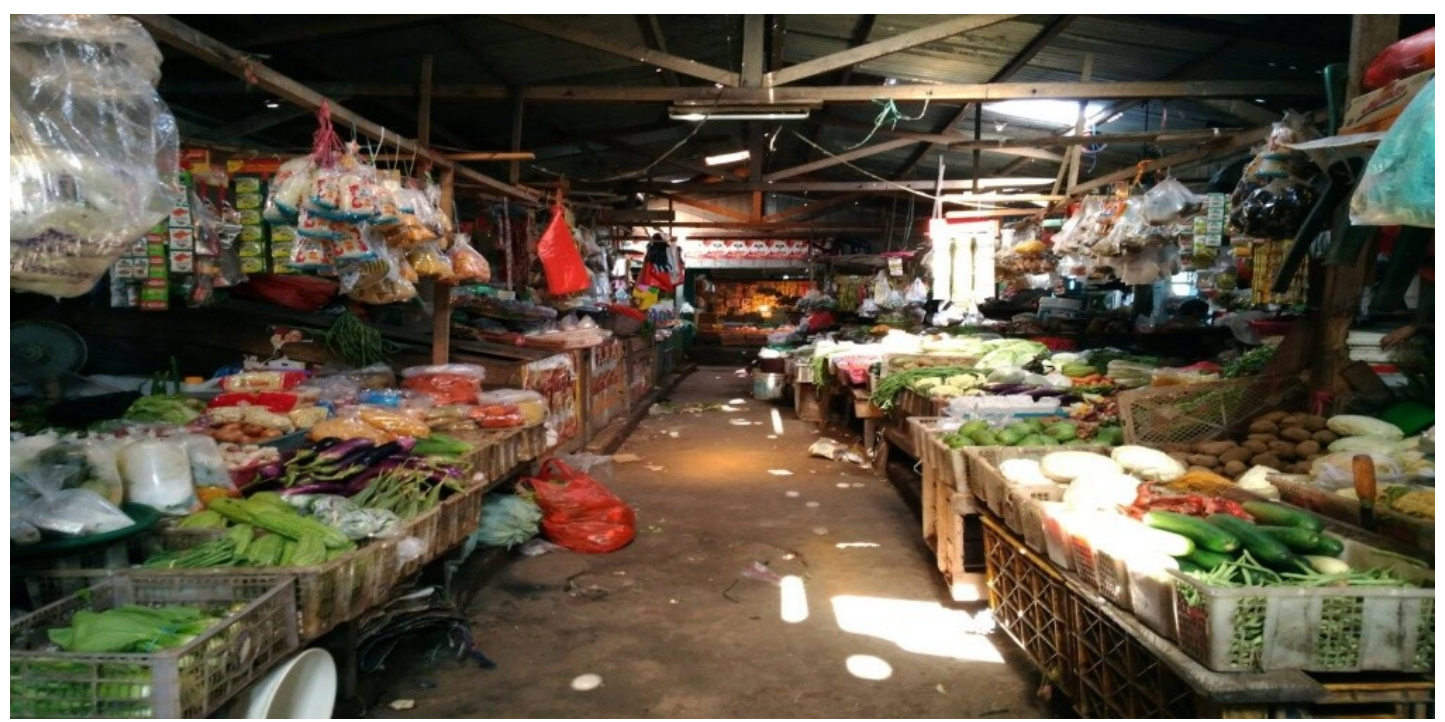

Gambar 2. Pasar Manggar

Hasil tangkapan yang ada kemudian dijual oleh pedagang-pedagang yang beroperasi di Pasar Manggar yang menyediakan ikan-ikan segar bagi warga sekitar. Sebagian hasil tangkapan biasanya akan diolah oleh usaha lokal menjadi produk pangan berupa amplang, berbagai macam kerupuk atau ikan asin. Warungwarung makanan yang biasa disebut 'sari laut' yang khas dengan makanan olahan laut di sekitar kawasan ini juga salah satu konsumen terbesar di Pasar Manggar tersebut.

Pedagang-pedagang di Pasar Manggar ini rata-rata merupakan warga asli sekitar dan sebagian kecilnya berasal dari Teritip atau Lamaru. Pasar tradisional di Manggar ini merupakan pusat dari perekonomian Manggar, dimana banyak warganya membeli segala kebutuhannya disini. Di pagi hari, hasil tangkapan ikan yang masih segar-segar merupakan rebutan pagi para pengunjung untuk membelinya. Peternak-peternak sapi dan ayam di kawasan Manggar juga mendistribusikan daging segarnya di pasar ini. Ada pula distributordistributor khusus yang menjual barang dagangannya ke luar daerah seperti distributor kepiting lokal yang menyuplai kepiting-kepiting segarnya ke beberapa tempat makan di daerah perkotaan Balikpapan dan bahkan menjalin hubungan profesional yang erat dengan sudah menjadi langganan tetap selama bertahun-tahun.

Menurut Prasiyasa, penyediaan fasilitas makanan dan minuman tentu saja tidak dapat dipisahkan dari kebutuhan wisatawan sebagai bagian dari produk wisata. Dengan alasan bahwa keinginan untuk memberi kepuasan bagi wisatawan, membuat para pengusaha yang bergerak dalam penyediaan makanan dan minuman melakukan berbagai usaha untuk menyediakan berbagai hidangan yang sesuai dengan "taste" wisatawan yang datang dari berbagai negara. Dengan gencarnya usaha untuk memperkenalkan makanan dan minuman tradisional membuat wisatawan mancanegara mulai menyesuaikan dan menyukai makanan dan minuman khas dari tempat wisata yang mereka kunjungi (Araujo, 2016).

\section{Masyarakat Pesisir dan Desa Wisata}

Masyarakat pesisir menurut Saad dan Basuki didefinisikan sebagai kelompok orang yang tinggal di daerah pesisir dan sumber kehidupan ekonomi penduduk bergantung secara langsung pada pemanfaatn sumberdaya laut dan pesisir. Definisi ini pun bisa juga dikembangkan lebih jauh karena pada dasarnya banyak yang hidupnya bergantung pada sumber daya laut. Mereka terdiri dari nelayan pemilik, buruh 
nelayan, pembudidaya ikan dan organisme laut lainnya, pedagang ikan, pengolah ikan, pemasok faktor sarana produksi perikanan (Wibowo, Bahri, \& Harto, 2016).

Dalam bidang nonperikanan, Nikijuluw menjelaskan masyarakat pesisir bisa terdiri dari penjual jasa pariwisata, penjual jasa transportasi, serta kelompok masyarakat lainnya yang memanfaatkan sumberdaya nonhayati laut dan pesisir untuk menyokong kehidupannya. Definisi masyarakat pesisir yang luas ini tidak secara keseluruhan diambil, tetapi hanya difokuskan pada kelompok nelayan dan pembudidaya ikan serta pedagang dan pengolah ikan. Kelompok ini secara langsung mengusahakan dan memanfaatkan sumberdaya ikan melalui kegiatan penangkapan dan budidaya. Sebagian besar masyarakat nelayan pesisir ini adalah pengusaha skala kecil dan menengah (Wibowo, Bahri, \& Harto, 2016).

Berdasarkan uraian di atas mengenai masyarakat pesisir, potensi yang dimiliki oleh masyarakat tersebut sebenarnya telah ada untuk dikembangkan di sektor pariwisata. Hal tersebut dapat dilakukan melalui pelatihan-pelatihan pengelolaan pada hasil-hasil perikanan yang dimiliki dengan mengikuti perkembangan global yang dapat menarik tingkat wisatawan baik dalam negeri maupun mancanegara menjadikan wilayah pesisir dapat menjadi salah satu tempat wisata atau Desa wisata. Kekhasan kuliner masyarakat pesisir yang ditampakkan akan juga menambah daya tarik tersendiri bagi wisatawan. Selain itu, pemanfaatan pantai pesisir dalam berbagai budidaya kelautan yang dikemas atau dikreasikan untuk daya tarik wisatawan yang ingin terjun langsung mengetahui cara budidaya kelautan beberapa spesies laut dapat menjadi referensi menarik bagi wisatawan pula. Pemanfaatan lahan pesisir dengan membangun galeri-galeri atau museum bahari akan menambah tingkat pariwisata dari segi pendidikan bagi anakanak sekolah.

Pemfokusan pada program yang mencakup pelatihan kelautan dan perikanan, program pendidikan kelautan dan perikanan, program penyuluhan kelautan dan perikanan, program pembinaan dan pengembangan kapal perikanan, alat penangkapan ikan, dan pengawakan perikanan,

program

pengembangan pembangunan dan pengelolaan pelabuhan perikanan, program pelayanan usaha perikanan tangkap, meningkatnya pelayanan prima dan ketertiban usaha perikanan tangkap sesuai ketersediaan SDI (Sumber Daya Ikan) disetiap WPP (Wilayah Pengembangan Perikanan) secara akuntabel dan tepat waktu. Program pengelolaan sistem kesehatan ikan dan lingkungan dan pembudidayaan ikan, program sistem pembenihan ikan, program pengelolaan sistem, prasarana dan sarana pembudidayaan ikan, program peningkatan daya saing usaha dan produk KP (Kelautan dan Perikanan), program serapan pasar domestik hasil KP, program penguatan dan perluasan akses pasar luar negeri hasil kelautan dan perikanan, dan program pengembangan produk serta usaha pasca panen nonpangan hasil kelautan dan perikanan (Adhi, Tajrin, Zamroni, \& Rahardian, 2014).

Guna peningkatan global industri pariwisata saat ini merupakan industri penting sebagai penyumbang Gross Domestic Product suatu Negara dan bagi daerah Industri ini sebagai penyokong dari pendapatan asli daerah. Industri ini mampu memberikan kontribusi lebih dari $10 \%$ dari PAD. Hal inilah yang menyebabkan daerah berlomba-lomba untuk memperkenalkan potensi pariwisata yang memilikinya sehingga dapat menarik kunjungan wisata baik lokal maupun mancanegara. Berkembangnya sektor ini akan membawa dampak pada industri-industri terkait seperti hotel, rumah makan, biro travel, dan UKM di daerah-daerah kunjungan wisata karena dapat memproduksi dan menjual barangbarang cinderamata (Trisnawati, Wiyadi, \& Priyono, 2008).

\section{SIMPULAN}

Balikpapan khususnya daerah Manggar memiliki potensi kelautan yang sangat besar dan dapat menjadi modal bagi pengembangan pariwisata dan pendapatan asli daerah. Berkembangnya sektor ini akan membawa dampak pada industri-industri terkait seperti hotel, rumah makan, biro travel, dan UKM di daerah-daerah kunjungan wisata karena dapat memproduksi dan menjual barang-barang cinderamata. 


\section{SARAN}

Pemanfaatan pantai pesisir dalam berbagai budidaya kelautan yang dikemas atau dikreasikan untuk daya tarik wisatawan yang ingin terjun langsung mengetahui cara budidaya kelautan beberapa spesies laut dapat menjadi referensi menarik bagi wisatawan pula. Pemanfaatan lahan pesisir dengan membangun galeri-galeri atau museum bahari akan menambah tingkat pariwisata dari segi pendidikan bagi anak-anak sekolah.

\section{DAFTAR PUSTAKA}

Adhi, T. R., Tajrin, Zamroni, A., \& Rahardian, R. (2014). Potensi Indonesia Menuju Negara Maritim. Volume 10. Jakarta: Balai Besar Penelitian Sosial Ekonomi Kelautan dan Perikanan.

Anugrah, K., \& Sudarmayasa, I. W. (2017). Pembangunan Pariwisata Daerah Melalui Pengembangan Sumber Daya Manusia di Gorontalo. JUMPA. Volume 4. Nomor 1. Bulan Juli 2017, 33-46.

Araujo, E. B. (2016). Pengembangan Kuliner Lokal Sebagai Daya Tarik Wisata di Dili, Timur Leste. JUMPA. Volume 3. Nomor 1. Juli 2016, 15-27.

Djula, B. (2013, Nopember 08). Sumber Daya Alam dan Pertumbuhan Ekonomi. Retrieved from www.repisatory.ung.ac.id/1: http://repisatory.ung.ac.id/get/simlit_res/1/ 366/Sumber-Daya-Alam-danPertumbuhan-Ekonomi.pdf.

Fatmasari, D. (2014). Analisis Sosial Ekonomi dan Budaya Masyarakat Pesisir Desa Waruduwur, Kecamatan Mundu,
Kabupaten Cirebon. Al Amwal , 6, 144166.

Harto, S. (2014, Mei 20). Kajian Wisata Budaya Terpadu Dalam Rangka Mengoptimalkan Potensi Lokal dalam Meningkatkan Daya Saing Bangsa (Optimalisasi Wisata Kawasan Muara Takus, Kabupaten Kampar, Provinsi Riau). Retrieved November 25, 2017, from Repository University of Riau: http://repository.unri.ac.id/xmlui/handle/12 $3456789 / 6242$

Junaidi, \& Zulgani. (2011). Peranan Sumberdaya Ekonomi Dalam Pembangunan Ekonomi Daerah. Jurnal Pembangunan Daerah Edisi III , 27-33.

Trisnawati, R., Wiyadi, \& Priyono, E. (2008). Analisis Daya Saing Industri Pariwisata untuk Meningkatkan Ekonomi Daerah (Kajian Perbandingan Daya Saing Pariwisata Antara Surakarta dengan Yogyakarta) . Jurnal Ekonomi Pembangunan Kajian Ekonomi Negara Berkembang. Volume 13. Issue 2, 61-70.

Wibowo, H., Bahri, E. S., \& Harto, P. P. (2016). Optimalisasi Peran Masyarakat Nelayan Batam dalam Pengembangan Ekonomi. SOSIO DIDAKTIKA , 3, 92-104.

Witarsa. (2015). Model Pengembangan Ekonomi Masyarakat Pesisir Berbasis CoManagement Sumberdaya Perikanan di Kabupaten Pontianak. Prosiding Seminar Nasional Profesionalisme Pendidik dalam Dinamika Kurikulum Pendidikan di Indonesia pada Era MEA (pp. 764-784). Yogyakarta: Fakultas Ekonomi Universitas Yogyakarta. 